LOSARI: Jurnal Pengabdian Kepada Masyarakat

http://ojs.losari.or.id/index.php/losari

Volume 1 | Nomor 1 | Juni |2019

e-ISSN: 2684-8678 dan p-ISSN: 2684-9887

\title{
Pengenalan Dan Pelatihan Laporan Keuangan Bumdes Di Desa Galesong Baru Kabupaten Takalar
}

\author{
Asbi Amin ${ }^{1}$, Marwah Jusuf ${ }^{1}$, Niken Probondani Astuti ${ }^{2}$
}

Keywords :

Badan Usaha Milik Desa

Pengelolaan keuangan

Corespondensi Author

Akuntansi ${ }^{1}$, Manajemen $^{2}$ STIEM

Bongaya

Jl. Mapaodang

Email: asbiamin@gmail.com ${ }^{1}$

\section{History Artikel}

Received: April 2019

Reviewed: April 2019

Revised: Mei 2019

Accepted: Juni 2019

Published: Juni 2019

\begin{abstract}
Abstrak. Komitmen pemerintah sangat tinggi untuk mendorong kesejahteraan masyarakat desa. Salah satunya dengan menggelontorkan miliaran rupiah ke desa dalam bentuk dana desa. Dengan dana desa tersebut, banyak potensi ekonomi masyarakat desa yang bisa ditingkatkan sehingga tentu saja butuh penguatan lembaga. Salah satunya pembentukan Badan Usaha Milik Desa (BUMDes), yang diharapkan bisa memfasilitasi masyarakat dalam pendanaan, membantu pembinaan usaha, juga membantu memfasilitasi pemasaran produk milik warga.

Desa Galesong Baru merupakan salah satu desa yang mendapatkan bantuan dana. Permasalahan yang dihadapi BUMDes adalah pengetahuan pengelola mengenai laporan keuangan masih terbatas

Solusi yang ditawarkan antara lain (1) mengadakan sosialisasi mengenai BUMDes (2) pelatihan pembuatan laporan keuangan
\end{abstract}

\section{Pendahuluan}

\section{A.Analisis Situasi}

Dewasa ini, kegiatan pengembangan desa merupakan hal yang sangat diperhatikan semua pihak, baik pemerintah maupun swasta. Jika dimulai dari perkembangan desa, maka pemerintah maupun bangsa ini akan kuat. Jika saja semua desa di Indonesia kuat, maka perekonomian di Indonesia akan semakin kuat.

Hampir di setiap desa saat ini memiliki BUMDes, BUMDes merupakan badan usaha yang dimiliki oleh desa dimana seluruh atau sebagian modalnya dimiliki oleh desa melalui penyertaan secara langsung yang berasal dari kekayaan desa sehingga pengembangan BUMDes merupakan bentuk penguatan terhadap lembaga-lembaga ekonomi desa serta merupakan alat pendayagunaan ekonomi lokal dengan berbagai ragam jenis potensi yang ada di desa. Tujuan yang sangat mulia yaitu kesejahteraan masyarakat desa akan mampu tercapai jika saja perekonomian desa menguat. Potensi besar dan tangguh saat ini, dapat dijadikan pilihan sebagai roda perekonomian desa dengan pembentukan dan pengembangan Badan Usaha Milik Desa (BUMDes). Dengan eksistensi BUMDes tersebut bisa jadi lokomotif penggerak agar ekonomi desa dapat berkembang serta mampu mensejahterakan masyarakat desa dan mengurangi angka kemiskinan di desa

Pembentukan badan usaha milik desa ini juga berdasarkan pada Permendagri nomor 39 tahun 2010 pada bab II tentang pembentukan badan usaha milik desa. Pembentukan ini berasal dari pemerintah kabupaten/kota dengan menetapkan peraturan daerah tentang pedoman tata cara pembentukan dan pengelolaan bumdes. 
Asbi Amin, Marwah Jusuf, Niken Probondani Astuti. Pengenalan dan Pelatihan Laporan Keuangan BUMDes di Desa Galesong Baru Kabupaten Takalar

Selanjutnya pemerintah desa membentuk bumdes dengan peraturan desa yang berpedoman pada peraturan daerah.[1] Tujuan pendirian BUMDes

antara lain untuk meningkatkan pendapatan asli desa. Berangkat dari cara pandang itu, jika pendapatan asli desa dapat diperoleh dari BUMDes maka kondisi itu akan mendorong setiap pemerintah desa memberikan dukungan dalam merespon pendirian BUMDes. Meskipun dana desa yang digelontorkan pemerintah ke desa jumlahnya sangat besar, namun tidak serta merta bisa mengakselerasi pertambahan Badan Usaha Milik Desa (BUMDes). Forum Badan Usaha Milik Desa (BUMDes) Indonesia menyebut dari 27.067 BUMDes hanya sekitar $10 \%$ yang usahanya jalan. Sisanya tidak jalan, dan ada yang jalan tetapi tidak memberikan keuntungan.[2]

BUMDes Galesong Baru baru saja terbentuk di bulan Januari 2019. Masih minimnya pengetahuan warga desa mengenai BUMDes menjadi salah satu penghambat terbentuknya BUMDes. Padahal potensi yang dimiliki Desa Galesong Baru sangat besar. Sumber daya pertanian jagung, labu dan telur ikan layang. Disisi lain aparat dan pengelola juga terkendala kurangnya pengetahuan mengenai laporan keuangan.Sebagai sebuah institusi usaha, Badan Usaha Milik Desa (BUMDesa) wajib membuat laporan keuangan yang jujur dan transparan. Selain menjadi bahan monitoring dan evaluasi, laporan keuangan juga akan menjadi pedoman untuk langkah pengembangan BUMDes.

Peraturan Menteri Desa, Pembangunan Daerah Tertinggal dan Transmigrasi Republik Indonesia Nomor 4 Tahun 2015 Tentang Pendirian, Pengurusan dan Pengelolaan, dan Perubahan Badan Usaha Milik Desa pada Bab III pasal 12 ayat 3 menyatakan bahwa pelaksana operasional (direktur) berwenang membuat laporan keuangan seluruh unit usaha BUMDes setiap bulan. Selain itu, Peraturan Nomor 17 Tahun 2011 Tentang Petunjuk Pelaksanaan Badan Usaha Milik Desa pada Bab III menyatakan bahwa pelaksana operasional (direktur) berkewajiban membuat laporan keuangan konsolidasi dari setiap kegiatan unit usah BUMDes. Tentu saja hal ini harus berpedoman pada standar keuangan yang berlaku umum [3]

\section{B. Permasalahan Mitra}

Pengelolaan BUMDes harus dikelola secara professional dan mandiri. Sebagai sebuah lembaga yang diwajibkan mendapat profit maka kompetensi sumber daya manusia sangat dibutuhkan dalam pengelolaannya. Permasalahan yang dihadapi mitra adalah :

1. Pengetahuan masyarakat tentang BUMDes masih sangat terbatas

2. Minimnya pengetahuan dan keterampilan pengelola BUMDes mengenai laporan keuangan

\section{Metode Pelaksanaan}

Metode pelaksanaan untuk mendukung realisasi program ini adalah sosialisasi dan pelatihan

1. Mengadakan sosialisasi mengenai pengenalan BUMDes kepada pengelola, aparat desa dan masyarakat

2. Melaksanakan pengenalan dan pelatihan laporan keuangan bagi pengelola

\section{Hasil Dan Pembahasan}

Tahapan-tahapan kegiatan pelaksanaan adalah sebagai berikut;

\section{1) Tahapan kegiatan perencanaan}

Kegiatan perencanaan yang telah dilakukan adalah koordinasi dengan pihak Desa Galesong Baru sebagai tempat pelaksanaan kegiatan pengabdian. Tim pengabdi menyampaikan maksud dan tujuan dan meminta izin serta arahan. Kemudian waktu dan tempat menjadi prioritas perencanaan serta identifikasi calon peserta kegiatan.

\section{2) Tahapan Kegiatan Pelaksanaan}

Kegiatan dilaksanakan selama 1 hari. Kegiatan pada hari pertama diawali dengan sambutan pihak Desa Galesong Baru sebagai tuan rumah. Kegiatan dilanjutkan dengan paparan materi oleh narasumber. Narasumber menyampaikan materi tentang pengenalan BUMDes. Narasumber menyampaikan beberapa pertanyaan awal untuk mengetahui pemahaman dari peserta. Narasumber selanjutnya menyampaikan materi mengenai laporan keuangan, diantaranya mengenai pengantar akuntansi, pengenalan laporan keuangan dan jenis-jenisnya, dan praktek Kegiatan dilanjutkan dengan tanya jawab. 
Asbi Amin, Marwah Jusuf, Niken Probondani Astuti. Pengenalan dan Pelatihan Laporan Keuangan BUMDes di Desa Galesong Baru Kabupaten Takalar

Sebelum kegiatan pengabdian berakhir, narasumber mengajukan pertanyaan kepada peserta untuk mengetahui pemahaman mengenai materi yang disampaikan.

\section{c) Tahapan kegiatan evaluasi}

Tahapan kegiatan evaluasi dilakukan dengan tujuan;

(1) evaluasi proses pelaksanaan kegiatan pengabdian

(2) evaluasi peningkatan pemahaman peserta mengenai pembuatan laporan keuangan BUMDes
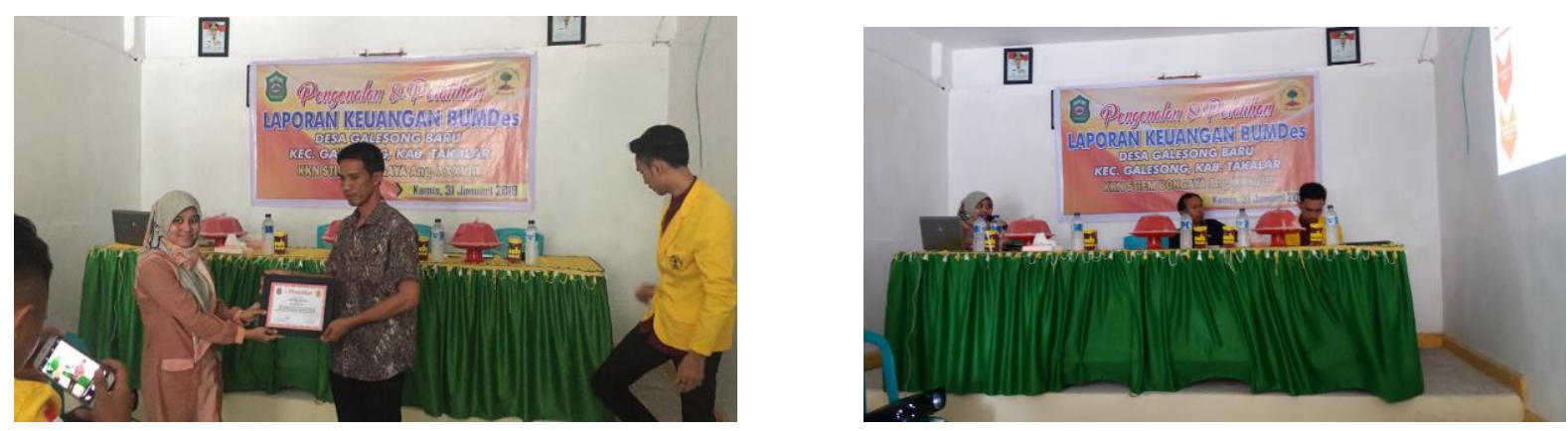

Gambar 1: Tim Memberikan Materi dalam Pengenalan dan Pelatihan Laporan Keuangan di Balai Desa Galesong Baru

\section{Simpulan Dan Saran Simpulan}

Potensi BUMDes di Desa Galesong Baru Takalar sangat besar. Mereka mampu bersaing dengan desa-desa lainnya dalam hal pendapatan karena memiliki sumber daya alam yang kaya namun belum dikelola dengan baik. Pengetahuan masyarakat serta aparat desa yang sangat minim menjadi kendala di desa ini.

Pengenalan BUMDes dan pelatihan laporan keuangan yang dilakukan sebagai solusi dari permasalahan yang dihadapi Desa Galesong Baru mendapat sambutan baik dari pengelola,aparat desa serta masyarakat. Ini terlihat dari antusiasnya peserta menanggapi dan memberikan pertanyaan terhadap materi yang disajikan oleh narasumber.

\section{Saran}

1. Dibutuhkannya pendampingan lebih lanjut ] untuk BUMDES Galesong Baru dalam hal pengelolaan dana baik dari pemerintah maupun dari pihak swasta.

2. Diperlukan pendampingan dalam praktek membuat laporan keuangan sehingga pengelola BUMDes mampu secara mandiri.

\section{Daftar Rujukan}

1. Peraturan Menteri Dalam Negeri Nomor 39 Tahun 2010 tentang Badan Usaha Milik Desa (c.2). Jakarta, Menteri Dalam Negeri.

2. Website:http://jogjapolitan.harianjogja.c $\mathrm{om} / \mathrm{read} / 2018 / 09 / 10 / 511 / 938867 / \mathrm{sdm}$ -hambatanutama-bumdes. Diakses pada tanggal 20 Oktober 2018

3. Peraturan Menteri Desa, Pembangunan Daerah Tertinggal dan Transmigrasi Republik Indonesia Nomor 4 Tahun 2015 Tentang Pendirian, Pengurusan dan Pengelolaan, dan Perubahan Badan Usaha Milik Desa 